\title{
KECERDASAN EKOLOGIS PESERTA DIDIK SMA DI KOTA BANDUNG
}

\author{
Oleh \\ Yoga Septian (1402164) \\ Departemen Pendidikan Geografi \\ SPS Universitas Pendidikan Indonesia
}

A. Abstarak

Kota Bandung memiliki sejumlah rmasalah lingkungan. Produksi sampah sangat banyak, mencapai 1.500 ton/hari (PD Kebersihan Kota Bandung: 2015). Penurunan air tanah mencapai 14,4 meter/tahun (Hamandi, 2006: 41). Banjir sering melanda Baleendah, Bojongsoang dan Dayeuhkolot saat musim penghujan. Kualitas air Ci kapundung ikut turun akibat pencemaran limbah dan sampah (Matahelumual 2010).

Subejek penelitian adalah seluruh peserta didik SMA di Kota Bandungn dengan sampel 200 siswa di SMAN 4, 9, 11, 21, 23, 25, SMA Pasundan 1 dan SMA St. Aloysius Bandung. Rumusan masalah terdiri dari: 1) Bagaimanakah pengaruh pengetahuan lingkungan terhadap perilaku ramah lingkungan peserta didik SMA di Kota Bandung, 2) Bagaimanakah pengaruh sikap peduli lingkungan terhadap perilaku ramah lingkungan peserta didik SMA di Kota Bandung.

Hasil penelitian menunjukan tidak ada pengaruh pengetahuan dan sikap peduli lingkungan terhadap perilaku ramah lingkungan. Diperlukan upaya seperti terus meningkatkan kualitas pembelajaran lingkungan hidup yang lebih bermakna. Pemerintah mengeluarkan kebijakan seperti pembatasan kepemilikan kendaraan pribadi. Sampai kapan warga sadar untuk tidak menginginkan kendaraan pribadi, sementara itu pada waktu yang sama polusi udara terus bertambah.

\section{B. Latar Belakang}

Interaksi antara manusia dengan lingkungan telah banyak menimbulkan berbagai kerusakan pada lingkungan. Suseno (Wilujeng, 2011: 6) mengatakan, banyak kerusakan lingkungan yang disebabkan oleh sikap teknokratis, yaitu sikap 
yang memandang lingkungan sebatas objek penguasaan kebutuhan manusia. Sikap ini ditemukan pada perusahan yang membakar hutan dan terlibat dalam berbagai degradasi lahan dengan alasan penghematan biaya operasional. Sikap teknokratis adalah sikap yang mengutamakan keuntungan ekonomi jangka pendek dari pada kelestarian lingkungan.

Berbagai kerusakan lingkungan hidup yang terjadi di seluruh belahan bumi telah mendorong Perserikatan Bangsa-Bangsa (PBB) untuk segera melaksanakan pertemuan tingkat dunia. Mulai dari pertemuan yang diselenggarakan di Kota Stockholm sampai dengan pertmuan terakhir yang diselenggarakan di Nusa Dua Bali, Indonesia pada tahun 2007. Hasil dari pertemuan penting ini adalah himbauan agar semua penduduk bumi mengambil tindakan sekecil apapun untuk menyelamatkan bumi.

Sebagai bagian dari komunitas dunia, Indonesia dan khusunya Kota Bandung tidak terlepas dari permasalah lingkungan. Produksi sampah di Kota Bandung mencapai 1.500 ton/hari (PD Kebersihan Kota Bandung: 2015). Angka ini membuat tumpukan sampah mudah ditemukan di TPS-TPS dan di berbagai sudut kota. Penurunan air tanah menurut Hamandi (2006: 41) mencapai 14,4 meter/tahun. Banjir sering melanda Baleendah, Bojongsoang dan Dayeuhkolot saat musim penghujan. Kualitas air Ci kapundung ikut turun akibat pencemaran limbah dan sampah (Matahelumual 2010).

Berbagai masalah lingkungan di atas tidak lepas dari perilaku manusia. Hisan (Pratiwi, 2015: 6) menyebutkan kebiasaan menggunakan produk sekali pakai mempengaruhi banyaknya tumpukan sampah. Penurunan muka air tanah menurut Hutasoit (2015) disebabkan karena eksploitasi hotel-hotel dan apartemen yang tidak terkontrol, sedangkan menurut Nurliana (2009: 261) disebabkan oleh alih fungsi lahan di kawasan tangkapan hujan. Banjir menurut Rosyidie (2013: 244) dipicu oleh penggundulan hutan di kawasan hulu sungai dan tumpukan sampah di saluran-saluran air.

Goleman (2009: 9) telah memperkenalkan konsep Kecerdasan Ekologis, dikatakan bahwa "kecerdasan ekologis memadukan keterampilan kognitif dengan empati terhadap segala bentuk kehidupan”. Keterampilan kognitif yang dimaksud 
adalah segala pengetahuan mengenai dampak dari berbagai perilaku manusia terhadap lingkungan, sedangkan rasa empati menyangkut kepedulian seseorang terhadap lingkungan. Empati akan terbangun ketika seseorang memandang dari pihak korban, baik manusia maupun makhluk hidup lain yang terkena dampak kerusakan lingkungan.

Kerusakan lingkungan yang meluas pada saat ini semakin menegaskan akan pentingnya perilaku ramah lingkungan, namun disayangkan pendidikan lingkungan hidup yang diharap mampu membentuk perilaku ramah lingkungan belum sesuai tujuan. Muhaimin (2015: 49) menuturkan, penyebab kegagalannya disebabkan karena pendekatan pembelajaran yang digunakan pendidik dalam ecopedagogi kurang mengeksplorasi siswa untuk menemukan informasi, menganalisis, dan membuat keputusan berdasarkan inkuiri, sehingga materi yang diberikan tidak menjadi perilaku yang ditampilkan sehari-hari.

Peserta didik SMA merupakan pelajar yang sudah mulai diberikan berbagai macam tanggung jawab. Posisinya sangat krusial, sepuluh sampai dua puluh tahun ke depan merekalah yang menjadi pemegang kebijakan, pengusaha dan penduduk yang dapat menentukan arah pengelolaan lingkungan hidup. Jika setiap individu sudah tertanam perilaku ramah lingkungan maka bukan hal yang mustahil masalah lingkungan hidup sudah tidak ada lagi. Berdasarkan penjelasan tersebut, penulis hendak menulis ringkasan penelitian yang dilaksanakan pada siswa dan siswi SMA di Kota Bandung.

\section{Rumusan Masalah}

Rumusan masalah dalam makalah ini ialah:

1. Bagaimanakah pengaruh pengetahuan lingkungan terhadap perilaku ramah lingkungan peserta didik SMA di Kota Bandung?

2. Bagaimanakah pengaruh sikap peduli lingkungan terhadap perilaku ramah lingkungan peserta didik SMA di Kota Bandung? 
D. Tinjauan Pustaka

\section{Permasalahan Lingkungan di Kota Bandung}

Menurut Wangsaatmaja dkk, (2006), masalah lingkungan hidup di Kota Bandung terdiri dari perubahan tata guna lahan, meningkatnya air permukaan (Run Off), turunnya permukaan air tanah, persampahan dan kualitas udara. Berdasarkan dua pendapat tersebut maka masalah-masalah lingkungan hidup yang ada di perkotaan ialah sebagai berikut.

a. Peningkatan Suhu Udara

Suhu di perkotaan akan naik seiring dengan meningkatnya jumlah bangunan. Gejala ini disebut dengan Urban Heat Island (UHI), yaitu gejala peningkatan udara panas pada lokasi yang memiliki kepadatan bangunan tinggi. Konsentrasi udara panas akan membentuk seperti pulau, tinggi di bagian tengah kemudian menipis ke masing-masing tepi seiring dengan penurunan luas lahan yang terbangun. Selain faktor bangunan, UHI juga dapat dipicu oleh tingginya aktivitas manusia dalam kegiatan industri dan transportasi (Badriyah 2014; 169).

b. Krisis Air

Krisis air di perkotaan sangat terasa ketika memasuki musim kemarau sekitar bulan juni sampai dengan bulan agustus. Hal ini terjadi karena; 1) laju perpindahan dan pertambahan penduduk ke perkotaan sangat tinggi, 2) penggunaan lahan yang tidak menggunakan kaidah konservasi tanah dan air, dan 3) eksploitasi air tanah yang berlebihan baik oleh gedung-gedung perkantoran, rumah sakit, pusat perbelanjaan, apartemen, pengusaha laundri, dan aktivitas lainnya (Prihatin; 2015). Ketiga faktor ini secara bersama-sama membentuk siklus rutin yang dinamakan krisis air.

c. Pencemaran Udara

Pencemaran udara merupakan hadirnya satu atau lebih gas pada komposisi udara ideal dalam jumlah dan/atau masa waktu yang dapat menyebabkan gangguan pada kesehatan manusia, kehidupan floran dan fauna ataupun kerusakan material (Canter, 1996 dalam KLH, 2010). Aktifitas di sektor transportasi, industri, komersil dan domestik dapat menyumbang 
pencemaran udara. Penggunaan energi seperti batu bara, minyak bumi, gas alam dan lain sebagainya di semua jenis kegiatan manusia merupakan penyumbang terbesar bagi pencemaran udara di perkotaan.

d. Sampah

Sampah merupakan hasil sisa dari kegiatan manusia dan/atau proses alam yang berbentuk padat, terdiri dari sampah rumah tangga dan sejenis sampah rumah tangga (PERMEN Dalam Negeri, 2010). Sampah merupakan material alami yang dihasilkan makhluk hidup melalui proses metabolisme tubuh baik padat maupun cair. Sampah menjadi masalah ketika kuantitasnya banyak sehingga lingkungan tidak mampu menetralisir kembali secara alami (Mulasari, dkk, 2014: 35). Sampah yang banyak ini nantinya akan mencemari lingkungan dan mengganggu estetika lingkungan.

\section{Kecerdasan Ekologis}

Membiarkan air terus mengalir ketika mandi, membuang tidak pada tempatnya atau membiarkan TV menyala padahal tidak ditonton merupakan contoh perilaku tidak ramah lingkungan. Goleman (2009: 9) memberikan sumbangsih cara merubah perilaku buruk tersebut dengan nama kecerdasan ekologis. Disebutkan bahwa kecerdasan ekologis merupakan keterampilan memadukan kempetensi kognitif dengan rasa empati terhadap lingkungan. Kompetensi kognitif dimaksudkan sebagai pengetahuan tentang lingkungan, sedangkan rasa empati sebagai kepedulian terhadap lingkungan.

a. Pengetahuan Lingkungan

Pengetahuan (knowledge) merupakan hasil tahu. Tahu akan ada setelah individu melakukan penginderaan terhadap objek. Penginderaan dilakukan dengan menggunakan alat indera yang terdiri dari mata, telinga, hidung, lidah dan kulit. Dari kelima indera tersebut, mata dan telingan paling banyak menyumbang pengetahuan kepada manusia. Ilmu merupakan bagian dari pengetahuan manusia selain seni dan agama (Suriasumantri, 2009: 104). Terdapat enam indikator yang termasuk ke dalam pengetahuan lingkungan (Muhaimin, 2015: 124), yaitu: 
1) Pengetahuan tentang penyebab masalah lingkungan.

2) Pengetahuan tentang dampak dari masalah lingkungan.

3) Pengetahuan mengenai solusi penyelesaian masalah lingkungan.

4) Pengetahuan tentang prediksi masalah lingkungan di masa mendatang.

5) Pengetahuan tentang masalah-masalah lingkungan dalam kehidupan sehari-hari.

6) Pemahaman tentang ketergantungan manusia dan lingkungan serta ketergantungan diantara individu, masyarakat dan bangsa dalam mengelola lingkungan hidup baik dalam konteks lokal maupun global.

Seseorang dikatakan ahli apabila sudah menguasai keempat dimensi pengetahuan di dalam ilmu yang digelutinya. Pengetahuannya tidak terbatas pada banyaknya mengetahui berbagai hal dari disiplin ilmu yang dikuasai, tetapi tertata secara sistematis yang mencerminkan pemahaman mendalam mengenai hubungan antar variabel yang diketahui. Pada tahap ini seorang ahli mampu menjelaskan berbagai fenomena di lapangan dengan baik. Selanjutnya, seorang ahli juga dituntut untuk mampu memberikan solusi dan mengaplikasikan, serta mampu memilihkan solusi yang paling baik.

b. Sikap Peduli Lingkungan

Sikap peduli lingkungan dipahami sebagai perasaan orang yang peduli terhadap kelestarian lingkungan. Sikap ini tidak dapat diketahui langsung, tetapi diketahui melalui perilaku yang dilakukan. Misalkan, tidak membuang sampah ke sungai, berusaha menjaga kelestarian hutan dari penebangan liar dan sebagainya. Sikap ini sangat diperlukan, mengingat dewasa ini telah banyak lingkungan yang sudah rusak akibat pemanfaatan lingkungan yang tidak baik. Kondisi seperti ini lebih nampak pada kehidupan masyarakat di kota-kota besar seperti di Kota Bandung.

Sikap peduli lingkungan peserta didik merupakan perubahan perilaku peserta didik yang ditunjukan oleh pemahaman, perasaan dan kecenderungan untuk mengaplikasikan pengetahuan lingkungan yang dimilikinya melalui tindakan yang memberikan dampak positif bagi lingkungan. Seperti menjaga kebersihan dan berusaha mencegah pengaruh buruk lainnya yang berpotensi 
merusak lingkungan. Menurut Van Liere dan Dunlap (Andromeda, 2009: 74), indikator sikap peduli lingkungan terdiri dari lima bagian yang dikonsepsikan dengan nama New Ecological Paradigm (NEP), terdiri dari:

1) Batasan untuk tumbuh

2) Pandangan anti antrophosentris

3) Kemungkinan krisis lingkungan

4) Gangguan terhadap keseimbangan lingkungan

5) Penolakan terhadap perilaku sewenang-wenang terhadap lingkungan

3. Perilaku Ramah Lingkungan

Sejak revolusi industri di tahun 1570, teknologi manusia yang digunakan untuk memenuhi kebutuhan hidup terus berkembang. Banyak industri beralih menggunakan tenaga mesin karena mampu meningkatkan produktifitas kerja. Efek samping dari kemajuan ini adalah kerusakan lingkungan yang tidak pernah terjadi sebelumnya. Kerusakan lingkungan dipicu oleh pemanfaatan teknologi modern yang dicampuri dengan hasrat manusia yang tidak pernah puas. Hasrat ini muncul pada pelaku usaha yang mengedepankan kepentingan ekonomi jangka pendek dari pada kelestarian lingkungan.

Green behavior is such which is generally (or according to knowledge of environmental science) judged in the context of the considered society as a protective way of environmental behavior a tribute to the health environment (Krajhanzl, 2010: 21). Menurut pengertian di atas, perilaku ramah lingkungan dipahami sebagai aktivitas yang memberikan dampak buruk sekecil mungkin terhadap lingkungan. Perilaku ini dicontohkan oleh seorang siswa yang lebih memilih bersepeda ketika pergi ke sekolah. Motif siswa ini dilatar belakangi oleh keinginan untuk mengurangi pencemaran udara.

Menurut Badan Pusat Statistik (BPS, 2013), perilaku ramah lingkungan dapat ditunjukan oleh perilaku di bawah ini.

a. Fasilitas Tempat Tinggal

1) Ketersediaan area terbuka

2) Penggunaan pencahayaan matahari untuk penerangan ruangan

3) Ketersediaan resapan air 
4) Keberadaan tanaman keras

b. Pemanfaatan Energi

1) Menggunakan lampu hemat energi

2) Menggunakan alat elektronik seperlunya

3) Memanfaatkan pencahayaan alami di ruangan saat siang hari

4) Mengurangi pemakaian listrik minimal 50 watt saat beban puncak

5) Mengatur suhu ruangan ber-AC di rumah pada suhu minimal $25^{\circ} \mathrm{C}$

c. Pemanfaatan Air

1) Memanfaatkan air bekas

2) Tidak membiarkan air mengalir percuma

3) Mencuci peralatan tidak dengan air mengalir

4) Menyediakan area resapan air di sekitar rumah

5) Menginvestasikan peralatan yang dapat menghemat air

d. Penggunaan Transportasi

1) Perawatan kendaraan bermotor

2) Menggunakan kendaraan umum dari pada kendaraan pribadi

3) Menggunaka moda kendaraan secara bersama-sama (Car Pooling)

4) Memilih kendaraan yang paling sedikit mengeluarkan emisi, seperti memilih menggunakan sepeda dari pada motor

e. Pengelolaan Sampah

1) Tidak membakar sampah

2) Membuang sampah sesuai jenisnya

3) Tidak membuang sampah sembarangan

4) Mendaur ulang sampah organik menjadi kompos

5) Tidak membuang sampah ke saluran got/sungai/laut

6) Menggunakan kembali barang yang masih layak pakai

7) Mendaur ulang sampah non-organik menjadi kerajinan

8) Membawa wadah sendiri untuk menggantikan kantong plastik

f. Partisipasi Pemeliharaan Lingkungan

1) Menjadi anggota komunitas peduli lingkungan.

2) Menyumbangkan harta benda bagi korban bencana. 
3) Keterlibatan diri dalam kerja bakti membersihkan lingkungan.

4) Menyampaikan informasi kepada orang lain terkait masalah lingkungan hidup.

5) Keterlibat dalam kegiatan penyelamatan lingkungan hidup, seperti penanaman pohon dan sebagainya.

\section{E. Hasil dan Pembahasan}

1. Uji Hubungan Antar Variabel

Tabel 1

Koralasi Antar Variabel

\begin{tabular}{|ll|r|r|r|}
\hline & & Pengetahuan & \multicolumn{1}{c|}{ Sikap } & Perilaku \\
\hline Pengetahuan & Pearson Correlation & 1 & $.250^{* *}$ & -.026 \\
& Sig. (2-tailed) & & .001 & .732 \\
& $\mathrm{~N}$ & 182 & 182 & 182 \\
\hline Sikap & Pearson Correlation & $.250^{* *}$ & 1 & .021 \\
& Sig. (2-tailed) & .001 & & .780 \\
& $\mathrm{~N}$ & 182 & 182 & 182 \\
\hline Perilaku & Pearson Correlation & -.026 & .021 & 1 \\
& Sig. (2-tailed) & .732 & .780 & 182 \\
& $\mathrm{~N}$ & 182 & 182 & \\
& & & & \\
& & & & \\
\end{tabular}

**. Correlation is significant at the 0.01 level (2-tailed).

Hubungan antara variabel bebas dengan variabel terikat dapat diketahui melalu uji Korelasi Pearson. Hubungan ini ditentukan melalui kriteria uji: jika nilai signifikasi (sig.) > 0,05 maka Ho diterima, tetapi jika nilai signifikasi (sig.) < 0,05, Ho ditolak. Hipotesis statistik untuk uji hubungan variabel bebas (X) dengan variabel terikat (Y) adalah sebagai berikut.

a. Hubungan antara pengetahuan lingkungan dengan perilaku ramah lingkungan

Ho : Tidak ada hubungan antara pengetahuan lingkungan dengan perilaku ramah lingkungan.

Ha : Ada hubungan antara pengetahuan lingkungan dengan perilaku ramah lingkungan. 
b. Hubungan antara sikap peduli lingkungan dengan perilaku ramah lingkungan

Ho : Tidak ada hubungan antara sikap peduli lingkungan dengan perilaku ramah lingkungan.

Ha : Ada hubungan antara sikap peduli lingkungan dengan perilaku ramah lingkungan.

Berdasarkan tabel 1, diketahui nilai sig. pengetahuan lingkungan terhadap perilaku ramah lingkungan pada tarap kepercayaan 95\% sebesar 0,732. Angka ini lebih besar dari 0,05 , oleh karena itu Ho yang diterima sehingga dapat disimpulkan bahwa tidak ada hubungan antara pengetahuan lingkungan dengan perilaku ramah lingkungan. Sama halnya dengan hubungan sikap peduli lingkungan terhadap perilaku ramah lingkungan. Berdasarkan tabel 1, nilai sig. kedua variabel tersebut 0,780. Angka ini lebih besar dari 0,05, karena itu tidak ada hubungan antara sikap pedul lingkungan dengan perilaku ramah lingkungan.

\section{Uji Pengaruh Antar Variabel}

Pengaruh antara variabel bebas dengan variabel terikat ditentukan melalui uji t. Analisis ini dilakukan untuk mengetahui pengaruh secara linier antara variabel independen terhadap variabel dependen. Ada atau tidak adanya pengaruh dintentukan berdasarkan kriteria: jika nilai signifikansi (sig.) > 0,05 maka Ho diterima, tetapi jika nilai signifikansinya $<0,05$ maka Ho ditolak. Hipotesis statistik dari uji pengaruh variabel bebas $(\mathrm{X})$ dengan variabel terikat adalah sebagai berikut:

a. Pengaruh antara pengetahuan lingkungan terhadap perilaku ramah lingkungan

Ho : Pengetahuan lingkungan tidak mempengaruhi perilaku ramah lingkungan.

Ha : Pengetahuan lingkungan mempengaruhi perilaku ramah lingkungan.

b. Pengaruh antara sikap peduli lingkungan terhadap perilaku ramah lingkungan 
Ho : Sikap peduli lingkungan tidak mempengaruhi perilaku ramah lingkungan.

Ha : Sikap peduli lingkungan mempengaruhi perilaku ramah lingkungan.

Tabel 2

Uji Pengaruh variabel bebas terhadap variabel terikat

\begin{tabular}{|c|c|c|c|c|c|c|}
\hline & \multirow{2}{*}{ Model } & \multicolumn{2}{|c|}{ Unstandardized Coefficients } & $\begin{array}{l}\text { Standardized } \\
\text { Coefficients }\end{array}$ & \multirow{2}{*}{$\mathrm{t}$} & \multirow{2}{*}{ Sig. } \\
\hline & & $\mathrm{B}$ & Std. Error & Beta & & \\
\hline \multirow[t]{3}{*}{1} & (Constant) & 73.043 & 6.573 & & 11.112 & .000 \\
\hline & Pengetahuan & -.064 & .149 & -.033 & -.425 & .671 \\
\hline & Sikap & .043 & .113 & .029 & .376 & .707 \\
\hline
\end{tabular}

a. Dependent Variable: Perilaku

Berdasarkan tabel 2, diketahui nilai 0,671 untuk signifikansi variabel pengetahuan lebih besar dari 0,05, dengan demikian kesimpulan untuk pengaruh pengetahuan lingkungan terhadap perilaku ramah lingkungan tidak ada. Begitupun dengan pengaruh sikap peduli lingkungan terhadap perilaku ramah lingkungan. Berdarakan tabel 2, nilai signifikansinya lebih besar dari 0,05 sehingga dapat disimpulkan bahwa sikap peduli lingkungan peserta didik SMA di Kota Bandung tidak mempengaruhi perilaku ramah lingkungan.

Perilaku ramah lingkungan belum meresap ke dalam diri peserta didik. Perilaku menurut Lickona (2015: 76) dipengaruhi oleh pengetahuan dan sikap. Pengetahuan dalam tingkat paling tinggi adalah keyakinan yang dimana keyakinan ini memdorong perasaan positif atau negatif terhadap suatu objek. Keyakinan ditambah dengan kecintaan terhadap kebaikan akan melahirkan berbagai perbuatan baik yang besumber dari hati nurani. Perilaku ramah lingkungan yang ditampilkan peserta didik masih dalam tahap pembiasaan dari pihak sekolah.

\section{F. Kesimpulan dan Saran}

Lingkungan hidup sangat mempengaruhi manusia, baik dan buruknya kondisi lingkungan akan mempengaruhi kualitas hidup manusia. Dengan demikian sangat diperlukan perilaku ramah lingkungan agar generasi mendatang masih merasakan indahnya lingkungan yang lestari. Masih disayangkan perilaku ramah lingkungan 
berlum terinternalisasi kedalam diri karena: 1) pengetahuan lingkungan peserta didik belum menjadi faktor pendorong untuk berperilaku ramah lingkungan 2) kepedulian terhadap lingkungan juga belum menjadi faktor pendorong untuk berperilku ramah lingkungan.

Saran dalam tulisan ini adalah 1) pendidik hendaknya terus meningkatkan kualitas pembelajaran lingkungan hidup supaya kegiatan belajar lebih bermakna. 2) berharap agar warga memiliki inisiatif untuk berperilaku ramah lingkungan ternyata sulit, sedangkan masalah lingkungan perlu segera diatasi, maka dari itu perlu ada kebijakan tegas dari pemerintah. Misalkan, pemerintah mengeluarkan kebijikan pembatasan kendaraan pribadi. Sampai kapan warga sadar untuk tidak menginginkan kendaraan pribadi, sementara itu pada waktu yang sama polusi udara terus bertambah.

\section{G. Daftar Pustaka}

1. JURNAL

Andromeda. M.F.K. (2009): Relevansi Status Sosial Ekonomi Terhadap Kepedulian Lingkungan Hidup Dalam Konteks Indonesia Sebagai Negara Berkembang. Jakarta. Universitas Indonesia

Badriyah, Imelda Ummiyatul (2014): Indikasi Berhentinya Urban Heat Island (Suhu) di Bali Saat Nyepi. Jakarta. Puslitbang BMKG

Hamandi, Dadi dkk. (2006): Konservasi Air Tanah di Bandung dan Sekitarnya. Bandung. Departemen Geologi dan Tata Lingkungan

Hutasoit, Lambok M. (2009): Kondisi Permukaan Air Tanah dengan dan Tanpa Peresapan Buatan di Daerah Bandung: Hasil Sumulasi Numerik. Bandung. Institut Teknologi Bandung

Krajhanzl, J. (2010): Environmental and Proenvironmental Behavior. Journal of Health Education

Matahelumual, Bethy C. (2010): Kajian Kualitas Air Sungai Sebagai Sumber Air Minum PDAM (Sungai Citarum dan Sungai Cikapundung). Bandung. Badan Geologi Kementrian Energi dan Sumber Daya Mineral 
Mulasari, Asti Surahma dkk (2014): Kebijakan Pemerintah Dalam Pengelolaan Sampah Domestik. Yogyakarta. Universitas Ahmad Dahlan

Nurliana, Leni dkk. (2009): Potensi Imbuhan dan Imbuhan Air Tanah Cekungan Air Tahan Bandung. Bandung. Institut Teknologi Bandung Pratiwi dan Nugroho, Candra Setya. (2015): Studi Pengaruh Pengetahuan dan Perilaku Warga Kecamatan Coblong, Kota Bandung Dalam Menyikapi Sampah Rumah Tangga terhadap Akumulasi Sampah Rumah Tangga. Bandung. Lembaga Administrasi Negara

Prihatin, Rohani Budi. 2013: Problem Air Bersih di Perkotaan. Jakarta. DPR Rosyidie, Arief (2013): Banjir: Fakta dan Dampaknya Serta Pengaruh dari Perubahan Guna Lahan. Bandung. Institut Teknologi Bandung

Wangsaatmaja, Setiawan, dkk. (2006): Permasalahan dan Strategi Pembangunan Lingkungan Berkelanjutan, Studi Kasus: Cekungan Bandung. Bandung. BPLHD Jawa Barat dan Institut Teknologi Bandung

Wibowo, Istiqomah. (2009): Pola Perilaku Kebersihan: Studi Psikologi Lingkungan Terhadap Pengelolaan Sampah Perkotaan. Depok. UI

Wilujeng, Sri Rahayu. (2003): Mencari Landasan Etis Bagi Upaya Membudayakan Pengelolaan Lingkungan Yang Bertanggung Jawab. Semarang. Universitas Diponegoro

\section{BUKU}

BPS. (2013): Indikator Peduli Lingkungan Hidup 2013. Jakarta. BPS Golleman, Daniel. (2009): Ecological Intellegen. Jakarta. PT. Gramedia Muhaimin. (2015): Membangun Kecerdasan Ekologis. Bandung. Alfabeta Suriasumantri, J. S. (2009): Filsafat Ilmu Sebuah Pengantar Populer. Jakarta. Pustaka Sinar Harapan

3. WEB

PD. Kebersihan Kota Bandung. (2015): Produksi Sampah di Kota Bandung. Bandung. PD. Kebersihan Kota Bandung 


\section{PERATURAN}

Pemerintah RI. (2012): PP No. 81 Tahun 2012. Jakarta. Pemerintah RI 